\title{
In-Between Spaces. Pluralism and Hybridity as Elements of a New Paradigm for Religion in the Modern Age
}

\author{
Michaela Pfadenhauer ${ }^{1}$
}

Published online: 14 March 2016

(C) The Author(s) 2016. This article is published with open access at Springerlink.com

\begin{abstract}
We are living in an age of pluralization in which religiosity and secularity are not mutually exclusive. With subversive intent, Peter L. Berger relativizes with this thesis his criticism of secularization theory. In the light of the persistence and widespread nature of religion and religiosity, Berger still considers secularization theory's assumption that modernization and secularization go hand in hand to be empirically untenable. At the same time, however, he acknowledges that a "secular discourse" has asserted itself globally and has achieved a dominant position in society. This secular discourse also spreads throughout the mind of each individual, without (necessarily) driving out religiosity. The present article traces the lines of argumentation in Peter L. Berger's works that lead to the thesis of two pluralisms: the coexistence of different religions and the coexistence of religious and secular discourse. Moreover, it establishes a connection between the question of the simultaneity of religiosity and secularity and the debate on hybridity that is currently being conducted within German-speaking sociology. The author postulates that this focus on "in-between" spaces - that is, on plurality and hybridityrather than on dichotomies has the potential to trigger a new paradigm for religion in the modern age.
\end{abstract}

Keywords Plurality · Pluralism · Hybridity · Relativization · Religiosity · Secularity $\cdot$ Paradigm

Michaela Pfadenhauer

Michaela.pfadenhauer@univie.ac.at

1 Vienna, Austria 


\section{Introduction}

Can people be religious and secular at the same time? Religion is "the belief that there is a reality beyond the reality of ordinary experience, and that this reality is of great significance for human life" (Berger 2014: 17). Secularity means the questioning - or, at least, the conscious bracketing - of the existence of such a reality. Are religiosity and secularity not, therefore, mutually exclusive? Would our commonsense not say that God either exists or-to borrow Nietzsche's famous phrase-God is dead?

What poses a challenge for sociological analysis is the "both/and"-not only with regard to the individual but also to society per se. Is it possible to simultaneously propound both a religious worldview and a secular worldview that questions all things divine? Are religiously motivated terrorist attacks not shocking evidence of the hotbeds of conflict throughout the world that arise from the parallelism of religious and secular worldviews?

Pluralism, as defined by Peter L. Berger in his new book The Many Altars of Modernity, is his interpretation of this complex individual and social constellation: "Pluralism is a social situation in which people with different ethnicities, worldviews, and moralities, live together peacefully and interact with each other amicably" (2014: 1). Berger thus provides a situational description of pluralism that, despite his assertions to the contrary, has undertones of an attitude that celebrates the pluralist reality and could therefore be an element of a political program. ${ }^{1}$

Berger's question regarding the simultaneity of religiosity and secularity ties in with the current debate within German-language sociology about social hybridity and hybrid sociality (see Kron 2015), although he does not use these terms himself. The fundamental aim of this debate is to shift the sociological perspective to a "both/and" logic that does not replace the "either/or logic" but rather supplements it with "concepts that complement and blend with each other" (Beck and Grande 2007: 29). Unequivocalness is not thereby declared obsolete but rather fictionalwithout, however, denying its raison d'être. Giesen et al. (2015: 50) argue that, viewed from this perspective, the hybrid becomes the "cultural normal case," while unequivocalness must be considered the exception.

This focus on an "in-between," which circumvents thinking in dichotomies and binary codes, has explosive implications for both social theory and the theory of society. Not only with regard to religion, this perspective raises the question of whether it must be assumed (a) that people switch between two supposedly incompatible states, or (b) whether two supposedly distinct states merge to such an extent that "in-between" states arise (Giesen et al. 2015: 49). Berger (2014: 68f., 71f.; see also Berger et al. 1973: 37) maintains that religiously minded modern

\footnotetext{
${ }^{1}$ Berger and Zijderveld (2009: 7) distinguished plurality ("an empirically available social reality") and pluralism ("the attitude that welcomes the reality"). Although they acknowledged that what they called plurality was "more commonly known as pluralism," they eschewed the term pluralism "because the suffix 'ism' suggests an ideology". However, because Berger (2014: 1) found that when he used plurality he constantly had to explain what he was talking about (" (...) 'you know, like pluralism") he abandoned the terminological clarification that played such an important role in Berger and Zijderveld (2009) and now uses pluralism to describe the social reality rather than celebrate it.
} 
individuals are capable of sequentially engaging in secular and religious activities. In other words, they are capable of "code switching" within seconds between secular and sacred realities (as cited in Ammerman 2014: 103). With this processual understanding, Berger assumes the existence of two worlds, of which the secular is the "paramount reality." Here, he draws on Alfred Schutz's concept of multiple realities (although Schutz does not refer to religion) which assumes rapid, and sometimes abrupt, transitions between subuniverses of meaning (Schutz 1962). Ammerman (2014: 100ff.), on the other hand, tends more towards variant (b) above. In the "everyday stories of a wide range of Americans," she identified hybrid types of "spiritual narratives" (2014: 103): "Sometimes people are aware of moving back and forth, but just as often they seem to occupy a single location that is both secular and sacred at the same time." This contradicts Berger's assumption that the religious and the secular constitute distinct spheres. And, finally, Hannah Arendt (1998) sketches an "in-between" world in which plurality-the condition of the human condition-takes hold.

\section{Pluralism in the Mind}

Critical of the perspective adopted by Taylor (2007), Berger (2014) characterizes modernity not as a secular but rather as a pluralist age. And even though the modern age is especially characterized by pluralism, Berger (2014: 4) cites as examples of highly developed pluralist eras (a) the several centuries during which the cultures of East Asia along the Silk Road "demonstrated an exuberant religious pluralism," and (b) the period in the late Roman Empire during which Hellenism flourished. Hence, pluralism is not in itself a new phenomenon. However, Berger (2014: 5) identifies "two powerful agents of modern pluralism," namely, the printing press and the steam engine - in other words, science and technology.

In a study entitled Modernity, Pluralism and the Crisis of Meaning, which was commissioned by the Bertelsmann Foundation, Berger and Luckmann (1995) use the metaphor of the coffee maker to illustrate the process of this change in consciousness: The modernization of consciousness causes the taken-for-granted interpretations that lie in the "depths" (at the level that Alfred Schutz called the "world-taken-for-granted") to evaporate upward to the "sphere of insecurity, that which is not taken for granted, opinions, which I am in principle prepared to revise or even retract" (Berger and Luckmann 1995: 44). As a result, the residual (coffee) grounds of certain knowledge shrink.

Societies in which the modern form of pluralism is fully developed are societies in which "value systems and stocks of meaning are no longer the common property of all members of society" (Berger and Luckmann 1995: 29). From a sociology-ofknowledge perspective, not only general knowledge shrinks in pluralist times but also the stock of unquestioned, secure subjective knowledge. The individual no longer unquestioningly knows "about the world, how to behave in it, what is reasonable to expect, and, last but not least, who he is" (Berger and Luckmann 1995: 40).

In his latest book, Berger (2014: 28f.) develops the thesis of a "pluralism in the mind," in which a religious and a secular discourse coexist. Strictly speaking, this 
pluralism in the mind is composed of two pluralisms - the diversity of religious offerings, on the one hand, and the diversity of narratives that shape the secular discourse, on the other. Religiously minded individuals find themselves confronted with a complex and disparate situation: At the level of society, this situation corresponds to an institutional structure that is as differentiated as it is eroding. This complicates the question of how this coexistence can and must be perceived-as competition or conflict, as a switch, or as a synthesis?

When seeking an answer to this question, it is helpful to recall that a worldview, or, indeed the human mind, is not a coherent whole but rather an incoherent hodgepodge of movable pieces onto which order can be imposed only analytically:

- As in the case of the coffee-maker metaphor (Berger and Luckmann 1995: 44), Berger (2014: 29) locates the unquestioned certainties, the world-taken-forgranted, on the lowest level of this layer model. In her response to Berger, Ammerman (2014: 100) describes this level as the "inner core of taken-forgranted assumptions about the way the world works."

- On the middle level, Berger locates "cognitive and normative definitions of reality that are widely accepted" (2014: 29). By this he means explanations, justifications, and values "that we consensually share with our culture" (Ammerman 2014: 100). Because "culture" is not a nationally delimited vessel, it is difficult to determine what these shared explanations, justifications, and values actually are. Just how difficult this is, can be seen from the renewed Leitkultur (defining culture) debate in Germany and the Wertefibel (handbook of values) debate in Austria, which were triggered by the current migratory flows.

- Preferences and opinions that are held "until further notice" (Schutz) form the top layer-although this layer can no longer be regarded as having any great degree of certainty at all. This is the level with which we are most familiar. It contains, for example, the opinions that we quickly form, and just as quickly discard, while reading the newspaper, and our changing tastes, aesthetic tendencies, and political leanings, the fickleness of which is obviously also steadily increasing.

According to Berger, religion has now arrived in the latter sphere. Hence, faith, which was originally an unquestionable given, has been shifted from the "strongly institutionalized" background of human social life to the "de-institutionalized" foreground (Berger 2014: 6) and has become a matter of choice. This does not necessarily lead to an abandonment of faith. However, religious convictions are no longer taken for granted, but rather require a conscious decision. This is reflected in the fact that existing options are also-and, in most of the world, especiallyreligious (see Berger 2014: 31).

At this point, Berger corrects himself. For many years he held the view that fewer and fewer people experienced their lives as being interwoven with religion. ${ }^{2}$ Now,

\footnotetext{
2 "As there is a secularization of society and culture, so is there a secularization of consciousness. Put simply, this means that the modern West has produced an increasing number of individuals who look upon the world and their own lives without the benefit of religious interpretations" (Berger 1967: 107f.).
} 
however, he assumes that a secular discourse is permeating the religious discourse. This by no means results in religiosity being driven out of human consciousness. Rather, the consequence is an increase in complexity that can be described as "social hybridity," which goes hand in hand with "hybrid sociality." 3

\section{Societal Correlate of Pluralism in the Mind}

To adequately describe "pluralism in the mind," one must also focus on the institutions that serve as guarantors of the taken-for-granted. What characterizes a social order (i.e., an institutional structure) in which pluralism of the mind prevails? Berger points out that "all institutions out there in society have an internal correlate in consciousness" (2014: 34f.). Key to this is the process that social constructivist theory calls institutionalization: Social actions become habits, and these habits crystallize to form normatively and cognitively plausible programs for social action. They are then internalized in individual consciousness, with the result that they guide the individual in his actions and are perceived as his own subjective meaning rather than the meaning of an other.

For the longest period of time in human history, social life was "programmed" by religious institutions that jointly formed a "sacred canopy" (Berger 1967). Drawing on Gehlen's anthropology, Berger (2014: 6) uses Gehlen's distinction between a "strongly institutionalized" background of human social life and a "deinstitutionalized" foreground to emphasize not only the limits of this "programming" but also the way institutionalization dovetails with processes of deinstitutionalization. According to this perspective, the coercive nature of institutions (see Rehberg 1994) does not end beyond the boundaries of the institution but rather in the forecourt, which is accessible to doubt.

With regard to the origins of the secular discourse, Berger follows Eric Voegelin, who, he notes, described the breakdown of the mythological view of the world "as a move from 'compactness' (reality experienced as one unified whole) to 'differentiation' (opening up a gap between transcendence and immanence)” (2014: 51). According to Karl Jaspers (as cited in Berger 2014: 51), the breakdown of the compact cosmos occurred during the "'axial age' (somewhere between the eighth and fifth centuries BCE)." In modern times, the religious institutions themselves paved the way for secular discourse. According to Berger (2014: 59), one stepping stone was the integration of natural law, and thus a secular perspective, into Catholic moral theology; another was the Protestant Reformation, which marked the beginning of the separation of church and state as a means of protecting freedom of religion against theocratic tendencies. In the First Amendment to the Constitution of the United States, this separation advanced to the status of a political institution (Berger 2014: 60). And this epitome of secular discourse eventually became taken-

\footnotetext{
3 See, once again, the volume edited by Kron (2015), which documents the sociological debate on hybridity and, thus, the sociological reflection on the problem form of unity and difference. In their introduction to the latter work, Kron and Berger (2015: 13) note in relation to "friend and enemy," "war and peace," "politics and economics," "communication and technology," and "sense and nonsense" that the one cannot exist, or be meaningful, without the other, and that this is what renders the hybrid possible.
} 
for-granted knowledge as it went from being not only a mainstream culture of religious tolerance but also something that was represented in the consciousness of each individual citizen - on the middle level of certainty, where widely shared cultural values are located.

Over four decades ago, Berger elaborated in The Sacred Canopy (1967) the notion that secularization must have a correlate both in culture and society and at the level of consciousness. In Part II of that book, which he now considers to be outdated because in it he still adhered to secularization theory, he wrote:

By secularization we mean the process by which sectors of society and culture are removed from the domination of religious institutions and symbols. When we speak of society and institutions in modern Western history, of course, secularization manifests itself in the evacuation by the Christian churches of areas previously under their control and influence-as in the separation of church and state or the expropriation of church lands, or in the emancipation of education from ecclesiastical authority. (Berger 1967: 107)

In line with the mainstream view in the sociology of religion at the time, Berger (1967) still supported the thesis that modernization inevitably led to secularization. He maintained that the secularizing effect of modernization was rendered plausible by Max Weber's thesis of the "disenchantment of the world," a process that was significantly fostered in the Western world by Protestantism. ${ }^{4}$ Hence, secularization theory "stood in a long tradition of modern thought about religion" (Berger 2014: 18) that can be traced back via the founding fathers of sociology, Weber, Durkheim, and Comte, to the thinkers of the Enlightenment.

Since the French Revolution, the European intellectual and cultural elite has generally been anti-ecclesiastical. The so-called "intelligentsia," which Berger and Huntington (2002: 50) reconstructed as a "world intellectual culture," is a thoroughly secularized milieu. However, as such, it is the exception rather than the rule. In Berger's view, this milieu has been largely responsible for the persistence of the secularization theory paradigm.

In the light of the resurgence of Islam and the sometimes explosive global expansion of religious movements (especially Pentecostalism, the Pentecostal version of Evangelical Protestantism) Berger now considers secularization theory to be empirically untenable (Berger 2014; Berger and Zijderveld 2009). In taking this view, he does not overlook the fact that, as a result of mass education, the secularized attitude of the academic milieu has spread to more and more social strata. The plausibility of religious experiences is weakened when cognitive elites have a secularized worldview (see Wuthnow et al. 1984: 64). Empirically, however, religiosity not only persists at a global level, it is also growing. And to interpret this as a pre-modern or transient phenomenon—as secularization theory does-would be milieu- or Eurocentric.

Luckmann (1967) debunked secularization as a "modern myth" much earlier than Berger did. However, Berger, too, soon corrected his assumption of a

\footnotetext{
${ }^{4}$ For Protestantism "divested itself as much as possible from the three most ancient and most powerful concomitants of the sacred-mystery, miracle, and magic" (Berger 1967: 111).
} 
"necessary interdependence" (Pollack 2014: 114) between modernization and secularization (see Berger 1971a, 1971b). The only thing that is empirically tenable is a correlation between pluralization and secularization-and only in Western Europe. According to Berger, the mistake that the secularization theorists-and, in particular, European intellectuals-made was that they elevated a historical exception to the rule, and Western Europe to a global yardstick.

In Religious America-Secular Europe?, Berger et al. (2008) analyzed this exceptional case-Western Europe. Like any other historical phenomenon, secularization cannot be explained monocausally. Rather, there are a large number of reasons why Western Europe became a geographical exception. They include the tendency to attach particular importance to the relationship between church and state, something that struck Alexis de Tocqueville in 1831, when he compared religious observance in Europe and America: "He sought to make sense of this strange (for him, a French European) situation of religious vitality with reference to the separation of church and state in the United States" (Berger et al. 2008: 23f.). Even in colonial America, no church ever succeeded in achieving a dominant position that would have enabled it to develop an exclusive relationship with the temporal power. ${ }^{5}$ The First Amendment to the United States Constitution adopted in 1791 ideologically legitimated freedom of religion and the separation of church and state. As a consequence, churches were accorded merely the status of "voluntary associations." In Europe, by contrast, established, or state, churches persisted into the twentieth century and, as in the case of the Church of England, sometimes still exist. As a result, the churches have been closely identified with authority. The strikingly large numbers of people in Western Europe who either do not belong to, or do not attend, a church is, not least, an expression of dissatisfaction with the state.

When he first abandoned secularization theory in the late 1990s, Berger (1999) formulated the thesis of a counter-trend- "de-secularization" or "counter-secularization." Nowadays, however, he insists that the religious persists alongside the secular. In taking this view, he by no means denies the enormous consequences of modernization for religions, which had a monopoly position in the premodern era. Berger (2014: 48f.) acknowledges that pluralism changes the relation between religion and state and between clergy and laity. Moreover, "pluralism changes the relation of religious institutions with each other." Nowadays, religions find themselves in a competitive situation that forces them to make their respective meaning offerings appear attractive. This gives lay people the opportunity to choose between different religious purveyors of meaning and to put together their own eclectic packages of spiritual meaning. As a result, the religious institutions lose their hitherto existing power to impose sanctions, and their economic power dwindles because of decreasing membership. ${ }^{6}$

\footnotetext{
5 The attempt by the Puritans to establish Calvinism as the state church in Massachusetts failed, as did a similar attempt on the part of the Anglicans in Virginia. This failure was due not to the postulate of tolerance but to the opposition of competing religions.

${ }^{6}$ Religions can respond to this competitive situation by opening up or closing themselves off. In Berger's view, neither isolation from the outside world nor internal closure has a lasting prospect for success. The practical advice he gives to church institutions is to engage in ecumenical dialogue with competitors without sacrificing the fundamental tenets of their respective religions. This presupposes prior
} 
However, these diverse developments are captured only roughly by the term secularization. Hence, Berger uses the term religious pluralism to describe the competitive situation with all its consequences. The example of the enshrining of the separation of church and state in the First Amendment to the Constitution of the United States, alone, shows that the process that is subsumed under secularization is a process of differentiation that began in the "axial age" and-significantly fostered by the division of labor-still continues in the modern age. ${ }^{7}$ Moreover, with regard to the institutional structure of society, secularization is a process of religious deinstitutionalization (Berger 2014: 7). ${ }^{8}$ However, de-institutionalization is by no means limited to religious institutions, nor can it be halted by additional legitimation measures. For, as a result of pluralization, we are constantly confronted with alternatives for roles, identities, interpretation schemes, values, and worldviews. These alternatives force us to reflect; they successively undermine the takenfor-grantedness of institutions and slowly but surely erode them from within. Relativization is the term Berger uses to denote this process.

\section{Pluralization means Relativization}

"Modernity pluralizes" (Berger and Zijderveld 2009: 7; emphasis in the original). Berger is still convinced of this connection between modernization and pluralization. However, by acknowledging the existence of de-institutionalization, he undermines the notion of linearity inherent in modernization theory (just as his concept of de-secularization undermined the linearity inherent in secularization theory). Modernization is by no means a linear process, nor does it produce the same results everywhere and under all conditions.

Irrespective of the specific form that modernity takes, it has a reinforcing effect on pluralism. Demographically, population growth and migration reinforce pluralism because they give rise to extensive urbanization, thus causing more and more people of different origins to live together in an increasingly confined space. Economically, pluralism is fostered by the geographic and social mobility that accompanies industrialization and the market economy. Like media communication, this mobility is a constant reminder of the pluralism of lifestyles and mentalities. And politically, the rule of law and democracy serve as institutional guarantors of reasonably peaceful coexistence. Hence, Berger and Zijderveld defined plurality (which Berger now calls pluralism) as "a situation in which diverse human groups (ethnic, religious, or however differentiated) live together under conditions of civic peace and in social interaction with each other" (2009: 7).

\footnotetext{
Footnote 6 continued

clarification of the intrinsic and extrinsic elements of faith: What is considered to be ultimate truth must be defended; what is deemed to be "negotiable," may be negotiated (see Berger 1992: 63).

7 This understanding of structural secularization (as part of functional differentiation) constitutes the core of secularization theory (see Bruce 2002, 2011; Pollack 2003, 2013).

${ }^{8}$ Berger (2005) predicted that such processes of de-institutionalization would also take place in many Eastern European countries.
} 
Berger calls the downside of this undoubtedly desirable modern situation the "great relativizing cauldron" (1979: 9). The unquestionable nature of schemes of interpretation is relativized, as is the unassailability of value systems, and, indeed, every worldview. The resulting interpretation problems and uncertainties of moral evaluation are caused not by a shortage but rather by an oversupply of co-existing patterns of interpretation and sets of values.

Berger's trust in pluralism as a solution stems from the assumption thatespecially under urban conditions where people must inevitably have dealings with each other - this social situation perpetuates "cognitive contamination" (i.e., mutual influence in the course of everyday conversation). ${ }^{9}$ As a consequence, it also perpetuates relativization, which "is the insight that reality can be perceived and lived differently from what one had thought of as the only way. Or, put simply, things can be really, really different" (Berger 2014: 3).

Relativity is the price to be paid for modernity. This situation, which, following Helmut Schelsky, could be described as institutionalized permanent doubt, prompts the kind of counter-reactions that are outlined in detail by Berger and Zijderveld: At one extreme, all religious and secular fundamentalisms try to banish doubt once and for all; at the other extreme, doubt is elevated to the status of relativism-a phenomenon that the authors detect among some postmodern thinkers (Berger and Zijderveld 2009: 57). ${ }^{10}$

A central concept in Berger's latest work (2014) is discourse. Berger and Zijderveld (2009) identified discourse as a key term in postmodernist theory, an approach for which the authors displayed undisguised disdain, as it is characterized in their view by the idea that "there is no objective truth" and that "all narratives are equally valid" (2009: 52): "Although there are no objectively valid bodies of knowledge, there are different 'discourses,' always in the service of some existing or aspired-to power structure. Each discourse is a body of narratives" (2009: 55f.). Although Berger does not explicitly state it, "secular discourse" as he understands it is a package of bureaucratic, capitalist, technological, and many other narratives.

Berger concedes that secularization theory has a kernel of truth: "Modernity has indeed produced a secular discourse, which enables people to deal with many areas of life without reference to any religious definitions of reality" (Berger 2014: 51). However, he does not allude to the discourse concept's connotations as a postmodernist slogan against "objectively valid bodies of knowledge" and their empirical verifiability. He attaches more importance to the question of how religious pluralism can be politically managed. In view of the sociopolitical explosiveness of religious pluralism, he considers the social theory dimension of "pluralism in the mind" to be of secondary importance

\footnotetext{
9 However, it is also conceivable that the opposite may happen-namely, that a person with an unstable worldview may be persuaded that the worldview of his conversation partner is the right one and may become a passionate advocate of it. The fundamentalist zeal of the convert is a well-known phenomenon.

${ }^{10}$ Communities, groups, associations, families, neighbors, etc. offer relative certainty between these extremes. These social forms, which Gehlen called secondary institutions, mediate, as it were, between the individual and society, also with regard to superordinate value configurations.
} 


\section{Plurality and Hybridity}

The formula cuius regio, eius religio (the ruler decides the religion), which was the basis of the Peace of Augsburg (1555), and was reiterated in the Peace of Westphalia (1648), was the way in which the still relatively limited degree of religious pluralism (Catholicism and Protestantism) in the Holy Roman Empire was politically managed under the then-prevailing conditions of religiously homogeneous territories. Deliberately overstraining the analogy to make a point, I would argue that, in relation to "pluralism in the mind," Berger implies a somewhat similar "vision of peace" that one could sum up in the principle: "the field (of activity) decides the relevance structure."

Berger acknowledges the resulting tensions and burdens for religious consciousness. In his view, they can be managed only by navigating between relevance structures and relevance hierarchies (2014: 61). However, he refuses to see anything mysterious about the way people manage to do this: "For most religious believers, faith and secularity are not mutually exclusive modes of attending to reality; it is not a matter of either/or, but rather of both/and. The ability to handle different discourses (to use Alfred Schutz's term, difference relevance structures) is an essential trait of a modern person" (2014: 53).

Using the piloting of an airplane as an example, Berger makes it clear that even a religiously minded pilot is obliged to devote his full attention to the secular discourse during the flight. The distinction between "in the cockpit" and "outside the cockpit" reflects a sequential understanding of secularity and religion: "Perhaps, as soon as our [Japanese] pilot comes home and has changed into traditional clothing, he will sit before a little Buddhist shrine in the apartment and chant sutras or engage in meditation" (Berger 2014: 72).

Berger also processually interprets the following scene that he experienced at a Buddhist temple during a visit to Hong Kong:

In front of a large statue of the Buddha stood a middle-aged Chinese man in a business suit, bowed in a posture of devotion. In one hand he held an incense stick, in the other hand, a cell phone into which he was speaking. (...) This conversation could have had to do with any number of areas of the man's life, and may perhaps have been in the context of some business transaction. (...) Nevertheless, at this moment the man was simultaneously performing an act of worship (bowing with an incense stick in hand) and engaging in a mundane conversation. (...) While physically engaging in an act of Buddhist worship, he was also simultaneously engaged in what is usually a secular form of communication. He certainly seemed quite successful in managing this synthesis. (Berger 2014: 68f.)

Religiously minded individuals do not try to find a way out of this complex situation by simplifying it ${ }^{11}$ or by seeing it either as one thing or the other. Rather, according to Berger (2014: 88) they adopt an attitude of "multi-relationality," which Berger,

\footnotetext{
11 Berger et al. (1973: 209) identify simplification in the sense of the rejection of the dichotomy (here: of the public and private spheres) as a way of dealing with the "frustrations of multi-relationality."
} 
Berger, and Kellner defined as "a tension of consciousness characterized by a quick alertness to ever-changing constellations of phenomena" (1973: 37).

Although he emphasizes the simultaneity of the religious and the secular, and he recognizes people's ability to synthesize religion and secularity, Berger interprets the process from the perspective of a switch logic, and-despite the speed with which consciousness manages to switch between a religious and a secular attitudehe thus underscores the difference between the religious and secular realms. In his response to Berger, Pollack (2014: 120) classifies this new approach as a "a paradigm of differentiation theory" in the sense of functional differentiation rather than the problem form of unity and difference. Pollack sees in this a change of direction (not back to the classical, but) toward the analytical core of secularization theory. Above all, however, he also sees in the phenomenon of the pluralization of worldviews and religion the potential for a paradigm shift: "Also important is yet another question-What other relations between religious and secular discourse are imaginable and likely, apart from their co-existence: mutual exclusion, conflict, predominance of one over the other, subversion, mutual penetration, provincialization, isolation, persistence, revolutionary universalization?" (Pollack 2014: 115).

Like Berger, Nancy T. Ammerman, who considers herself to be on the periphery of the secularization debate, emphasizes the importance of conversation for religious consciousness, without conceiving of it as being reduced to the thinking of the individual. However, she does not stress the contaminating power of conversation but rather the consciousness-forming power of narratives, which is therefore not a social-psychological but rather a social phenomenon: "Religious consciousness is produced in conversation, carried by actors from one place to another, and re-deployed and re-worked in each new telling" (2014: 102). Contrary to what Berger assumes, Ammerman's empirical research, which focuses on "the everyday stories of a wide array of Americans" (2014: 101), did not reveal rapid code switching between the secular and the sacred. Rather, her findings suggest that, like "Spanglish" (a mix of Spanish and English characterized by the fact that Spanish and English words occur in the one sentence) something unique-a hybrid mix of the sacred and the secular-evolves during conversation.

Following this logic, and going even further than Pollack (2014), the elaboration of the "both/and" (i.e., sociological reflection on the figure of the simultaneity of the religious and the secular) has the explosive power to trigger a paradigm shift. A fundamental prerequisite for a paradigm shift is the existence of another paradigm that distinguishes between the religious and the secular. Everything hybrid is socially constructed, and the assumption of hybridity must always be preceded by a delineation from something that is non-hybrid and unequivocal. Paradoxically, a "both/and" logic methodologically presupposes "both the both/and and the either/ or" (Kron and Berger 2015: 7).

The socially constructed nature of social hybridity is reflected in its designation as something that overcomes the boundaries between things that were previously separated (Bullik and Schroer 2015: 215). ${ }^{12}$ With regard to religion, Peter L. Berger

\footnotetext{
12 The prime example is the body, which was determined for a long time by the nature-culture or naturalness-artificiality dichotomy. On man as a hybrid or a cyborg, see Haraway (1991).
} 
played a significant role in bringing about such a separation: Secularization theory, the core of which is the thesis that "modernity necessarily brings about a decline of religion" (2014: ix), not only cements the "either/or" nature of the religious and the secular but also manifests a classical sociological perspective. To be able, now, to conceive of the religious and the secular as simultaneous, one needs this typically modern distinction between religious and secular in order to be able to go beyond it. $^{13}$

Another way of conceiving of the religious and the secular as simultaneous (and one that would probably appeal more to Berger) is via Hannah Arendt's concept of plurality. Berger and Zijderveld considered the basic fact in their definition of plurality to be "the diversity in the groups making up a society" (2009: 8). In their view, plurality exists only if these groups do not engage in violent conflict but rather-despite their diversity_ "live together under conditions of civil peace and in social interaction" (2009: 7). Hannah Arendt (1998 [1958)]) locates plurality on an even more basic level-not at the level of the group but rather in the conditio humana. ${ }^{14}$ It is the execution of multiperspectivity in the sense of a diversity of irreducible perspectives on a common world; and it is a structural condition of being human that can be identified only through its phenomenal execution in the world.

Open Access This article is distributed under the terms of the Creative Commons Attribution 4.0 International License (http://creativecommons.org/licenses/by/4.0/), which permits unrestricted use, distribution, and reproduction in any medium, provided you give appropriate credit to the original author(s) and the source, provide a link to the Creative Commons license, and indicate if changes were made.

\section{References}

Ammerman, N. (2014). Modern altars in everyday life. In P. L. Berger (Ed.), Toward a paradigm for religion in a pluralist age (pp. 94-110). Boston, MA/Berlin: Walter de Gruyter/Mouton.

Arendt, H. (1998). The human condition (2nd ed.). Chicago: University of Chicago Press.

Beck, U., \& Grande, E. (2007). Cosmopolitan europe. Cambridge: Polity Press.

Benhabib, S. (2006). Hannah Arendt. Die melancholische Denkerin der Moderne. Frankfurt: Suhrkamp. Berger, P. L. (1967). The sacred canopy: Elements of a sociological theory of religion. New York: Anchor Books.

Berger, P. L. (1971a). Soziologische Betrachtungen über die Zukunft der Religion. Zum gegenwärtigen Stand der Säkularisierungsdebatte. In O. Schatz (Ed.), Hat die Religion Zukunft? (pp. 49-68). Graz: Styria.

Berger, P. L. (1971b). Secularization and the problem of plausibility. In K. Thompson \& J. Tunstall (Eds.), Sociological perspectives (pp. 446-459). Harmondsworth: Penguin Books.

Berger, P. L. (1979). The heretical imperative. Contemporary possibilities of religious affirmation. Garden City, NY: Anchor Press.

\footnotetext{
13 According to Latour (1993), this distinction is not really modern after all.

14 See in relation to this, Benhabib (2006: 171ff.). It would be interesting to critically compare Berger's concept of pluralism (aka plurality) with Arendt's concept of plurality against the background of secularization theory (which is something that has not yet been done), because Arendt is frequently interpreted as being an apologist for the decline, not of religion but of the public political realm in the modern age. In her analysis of Hannah Arendt's phenomenology of plurality, Loidolt (2015) notes that, in Arendt's view, only within this intersubjective fabric of human relations - that is, only by being with others-does one realize who one is. Plurality is thus a mode of execution (of speech and action): something that must be done.
} 
Berger, P. L. (1992). A far glory: The quest for faith in an age of credulity. New York: Free Press.

Berger, P. L. (Ed.). (1999). The desecularization of the world: Resurgent religion and world politics. Washington, DC: Ethics and Public Policy Center.

Berger, P. L. (2005). Religion and the west. National Interest, 75(80), 112-119.

Berger, P. L. (2014). The many altars of modernity. Toward a paradigm for religion in a pluralist age. Boston, MA/Berlin: Walter de Gruyter/Mouton.

Berger, P. L., Berger, B., \& Kellner, H. (1973). The homeless mind. New York: Random House.

Berger, P. L., Davie, G., \& Fokas, E. (2008). Religious America, secular Europe? A theme and variations. Aldershot: Ashgate.

Berger, P. L., \& Huntington, S. P. (Eds.). (2002). Many globalizations: Cultural diversity in the contemporary world. Oxford: Oxford University Press.

Berger, P. L., \& Luckmann, T. (1995). Modernity, pluralism and the crisis of meaning. Gütersloh: Bertelsmann Foundation Publishers.

Berger, P. L., \& Zijderveld, A. (2009). In praise of doubt. How to have convictions without becoming a fanatic. New York: HarperOne.

Bruce, S. (2002). God is dead: Secularization in the west. Oxford: Blackwell Publishing.

Bruce, S. (2011). Secularization. In defence of an unfashionable theory. Oxford: Oxford University Press.

Bullik, A., \& Schroer, M. (2015). Hybride Körper-(Re-)assembling the body? In T. Kron (Ed.), Hybride Sozialität—soziale Hybridität (pp. 201-222). Weilerswist: Velbrück.

Giesen, B., Le Maitre, F., \& Meise, N. (2015). Hybriditäten-Zwischenlagen-Heterogenitäten. In T. Kron (Ed.), Hybride Sozialität-soziale Hybridität (pp. 49-59). Weilerswist: Velbrück.

Haraway, D. (1991). Simians, cyborgs, and women: The reinvention of nature. New York: Routledge Taylor \& Francis.

Kron, T. (Ed.). (2015). Hybride Sozialität-soziale Hybridität. Weilerswist: Velbrück.

Kron, T., \& Berger, P. (2015). Einleitung (introduction). In T. Kron (Ed.), Hybride Sozialität-soziale Hybridität (pp. 7-16). Weilerswist: Velbrück.

Latour, B. (1993). We have never been modern (C. Porter, Trans.). Cambridge, MA: Harvard University Press.

Loidolt, S. (2015). Hannah Arendts Phänomenologie der Pluralität. In Paper delivered in Vienna at the symposium "Politik der Differenz" to mark the occasion of the 40th anniversary of Arendt's death.

Luckmann, T. (1967). The invisible religion. New York: MacMillan.

Pollack, D. (2003). Säkularisierung-ein moderner Mythos?. Tübingen: Mohr.

Pollack, D. (2013). Secularization. In Oxford bibliographies http://www.oxfordbibliographies.com/view/ document/obo-9780199756384/obo-9780199756384-0073.xml. Accessed on 13.02.2016.

Pollack, D. (2014). Toward a new paradigm for the sociology of religion? In P. L. Berger (Ed.), The many altars of modernity. Toward a paradigm for religion in a pluralist age (pp. 111-122). Boston, MA/ Berlin: Walter de Gruyter/Mouton.

Rehberg, K.-S. (1994). Institutionen als symbolische Ordnungen. Leitfragen und Grundkategorien zur Theorie und Analyse institutioneller Mechanismen. In G. Göhler (Ed.), Die Eigenart der Institutionen (pp. 47-84). Baden-Baden: Nomos.

Schutz, A. (1962). On multiple realities. In M. Natanson (Ed.), Collected papers I: The problem of social reality (pp. 207-259). The Hague: Nijhoff.

Taylor, C. (2007). A secular age. Cambridge: Harvard University Press.

Wuthnow, R., Hunter, J., Bergensen, A., \& Kurzweil, E. (1984). Cultural analysis. The work of Peter L. Berger, Mary Douglas, Michel Foucault and Jürgen Habermas (pp. 121-142). London: Routledge \& Kegan Paul. 